\title{
HIGH DEPENDENCY OF CHILLI FRUIT SET ON WILD POLLINATORS IN SOUTHERN INDIA
}

\author{
Johanna Yourstone ${ }^{\mathrm{a} *}$, Josefin Gunnarsson ${ }^{\mathrm{a}}$, Henrik G. Smith ${ }^{\mathrm{a}, \mathrm{b}}$, Hema Somanathan ${ }^{\mathrm{c}}$ \\ ${ }^{a}$ Department of Biology, Lund University. Sölvegatan 37, 22362 Lund, Sweden. \\ ${ }^{b}$ Centre for Environmental and Climate Science, Lund University. Sölvegatan 37, 22362 Lund, Sweden. \\ 'IISER TVM Centre for Research and Education in Ecology and Evolution (ICREEE), School of Biology, Indian Institute of \\ Science Education and Research, Thiruvananthapuram, Kerala, India
}

Journal of Pollination Ecology, 28(6), 2021, pp 65-74

DOI: $10.26786 / 1920-$

$7603(2021) 629$

Received 1 October 2020, accepted 27 January 2021

*Corresponding author:

johanna.yourstone@biol.lu.se

\begin{abstract}
Ongoing pollinator declines threaten the production of many entomophilous crops. Recent reports that yields of animal-pollinated crops in India are increasing less than pollinator-independent ones suggest the occurrence of pollen limitation. We experimentally evaluated if production of the common food crop chilli benefits from insect pollination and if crop production is constrained by lack of pollinators under field conditions. Experiments were conducted in eleven chilli fields distributed across a semi-arid agricultural landscape in Andhra Pradesh, India. The experimental treatments included open controls, open pollensupplemented flowers, and bagged flowers for pollinator exclusion. The fruit set from the two open treatments (control and pollen supplementation) was about three times higher than that from the exclusion treatment, suggesting strong dependence on insect pollination. Control and supplementation treatments did not differ, which suggests that there normally is sufficient pollination for chilli production in the area. Bees contributed $98 \%$ of flower visits. Flower visitor abundance correlated with higher fruit set, but only significantly so in the pollen supplemented treatment. While previous studies that are mostly conducted in greenhouse settings suggest that chilli reproduction does not depend much on animal pollination, our field study confirms that presence of animal pollinators increases fruit set. Future research should establish if this also applies to fruit quality and total yield. Our study highlights the importance of field-realistic experiments and warrants research on pollinator dependencies of other crops. The results have implications for crop production in an area where pollinator levels may be sufficiently high for crop pollination today but possibly not in the future due to environmental change.
\end{abstract}

Keywords-pollination, wild bees, ecosystem services, Apis dorsata, Capsicum annuum

\section{INTRODUCTION}

Ongoing pollinator declines are threatening both wild plants and crop production (Klein et al. 2007; Ollerton et al. 2011; Burkle et al. 2013; IPBES 2016). The reported declines have to a high degree been attributed to landscape changes mainly driven by agricultural expansion and intensification leading to e.g. habitat degradation, fragmentation, and fewer flowers for pollinators to forage on (Goulson et al. 2015; IPBES 2016). Apart from contributing to the pollination of almost $90 \%$ of the world's wild flowering plants (Ollerton et al.
2011), pollinators are also crucial for $3-8 \%$ of the worldwide agricultural production (Aizen et al. 2009), contributing to the yield of three quarters of the world's most common food crops (Klein et al. 2007). This dependency is relatively higher in the developing world, where the proportion of pollinator dependent crops is steadily increasing, and a higher proportion of essential micronutrients are derived from animal pollinated crops (Aizen et al. 2008; Chaplin-Kramer et al. 2014).

With one sixth of the world's population, India has a high demand for food production, with $60 \%$ 
of the total land area of India currently occupied by agricultural land use (FAOSTAT 2020c) and almost half of the working population depending on agriculture for their income (ILOSTAT 2020). Although India has an ancient history of agriculture which has largely shaped the landscapes of today (Gupta 2004), the country has undergone massive land-use changes since the time of independence, initially with land conversions creating more agricultural land, and more recently with an intensification of agriculture through practices such as the use of inorganic fertilizers and synthetic pesticides (Mishra 2002; Tripathi \& Prasad 2010). However, a development from small to large holdings seen with agricultural intensification in many other parts of the world (Lowder et al. 2016), has not happened in India (Tripathi \& Prasad 2010). Instead, an increased proportion of small holdings has been observed at the country scale.

In recent years, animal-pollinated crops in India have increased their yields at a significantly lower rate than pollinator independent crops (Basu et al. 2011), indicating a potential pollinator limitation in the country, which is in contrast to global patterns of equally increasing pollinator dependent and independent crops (Aizen et al. 2008). Many of the important food crops in India, such as tomato, eggplant, okra, coriander, many pulses, and chilli, are benefitted from insect pollination (Klein et al. 2007; Chaudhary \& Chand 2017), as are many of the agricultural products with the highest export value, such as cotton, castor oil, soybean cake, and chillies (Klein et al. 2007; Giannini et al. 2015; FAOSTAT 2020a). A reduced yield increase rate of these crops may therefore have consequences for both domestic food production and the economy (Chaudhary \& Chand 2017).

Chilli, Capsicum annuum, is a key spice in the Indian cuisine and is widely farmed in the country (FAOSTAT 2020b). A seminal study on the pollinator dependency of the world's most common food crops states that the yield of chilli only benefits "little" (>0 - 10\%) from insect pollination (Klein et al. 2007), based on the hitherto limited available evidence. Their conclusions are mainly based on greenhouse studies where it is shown that self-pollination is impaired indoors (cf. Jarlan et al. 1997; Cruz et al. 2005). Chilli is considered to be mainly self-pollinated (facilitated by wind) and does not require buzz-pollination, as do many other crops from the Solanaceae family, because of their poricidal anthers (De Luca \& Vallejo-Marín 2013). However, based on greenhouse experiments where higher fruit quality was seen in cross-pollinated than in selfpollinated chilli flowers (Cruz et al. 2005; Azmi et al. 2016), as well as outdoor experiments on the related habanero Capsicum chinense showing striking positive effects of insect pollination (Cauich et al. 2006; Landaverde-González et al. 2017), there is reason to believe that chilli yields benefit from pollinators to a higher degree than previously thought.

In this study we wanted to assess the impact of wild pollinators on the yield of chilli under natural outdoor conditions and evaluate the state of pollination services in southern India with chilli as a model crop. We conducted pollination experiments including pollen supplementation through hand pollination, pollinator exclusion and open controls to assess pollen limitation and the effect of wild pollinators on fruit set of chilli. Furthermore, we wanted to identify potential pollinators by observing flower visitors and relate the abundance of these to chilli fruit set. We also wanted to confirm that the most common flower visitors were collecting pollen from chilli, by visually analysing pollen from their hindlegs. We hypothesized that the chilli fruit set is lower in the pollinator exclusion treatment than in the control, and higher in the extra hand pollination treatment compared to the control. We further hypothesized an interaction between flower visitor abundance and treatment, where the two treatments are not affected by flower visitor abundance while the open control is positively affected by flower visitor abundance. Finally, we hypothesised that the most common flower visitors collect pollen from chilli.

\section{MATERIALS AND METHODS}

The study was done in a rural area of Chittoor district $\left(13.4788^{\circ} \mathrm{N}, 78.8383^{\circ} \mathrm{E}\right)$, Andhra Pradesh, in southern India (Fig. 1), an agricultural mosaic of partly irrigated small fields often bordered by semi-natural vegetation, small shrubby outcrops, and few larger coherent areas of dry deciduous forests, southern thorn forest, and scrub (Reddy et al. 2008). The climate is classified as tropical 
savannah-climate, with a mean annual rainfall of 400-750 $\mathrm{mm}$ and a daily temperature ranging from 20 to $40^{\circ} \mathrm{C}$ depending on season (Kottek et al. 2006; WorldWeatherOnline 2020). The study was conducted during winter and early summer between January-March 2018, with the year's lowest temperatures experienced in January slowly approaching the year's highest temperatures commonly experienced in April (WorldWeatherOnline 2020). During the study period there was barely any rainfall, as is common for that season. The crop diversity was high in most parts of the study area, including chilli, tomato, a wide variety of pulses, different types of cucurbits (cucumbers, watermelon, different gourds), mango, rice, sugar cane, millet and mulberry, with a few areas being completely dominated by rice paddies or mulberry fields. Both the native and the agricultural vegetation in the area was heavily invaded by alien species, mainly the bush Lantana camara, but also e.g. Ageratum conyzoides, Celosia argentea and Chromolaena odorata (Kohli et al. 2006). There is no tradition of domesticated honeybee practices in the area.

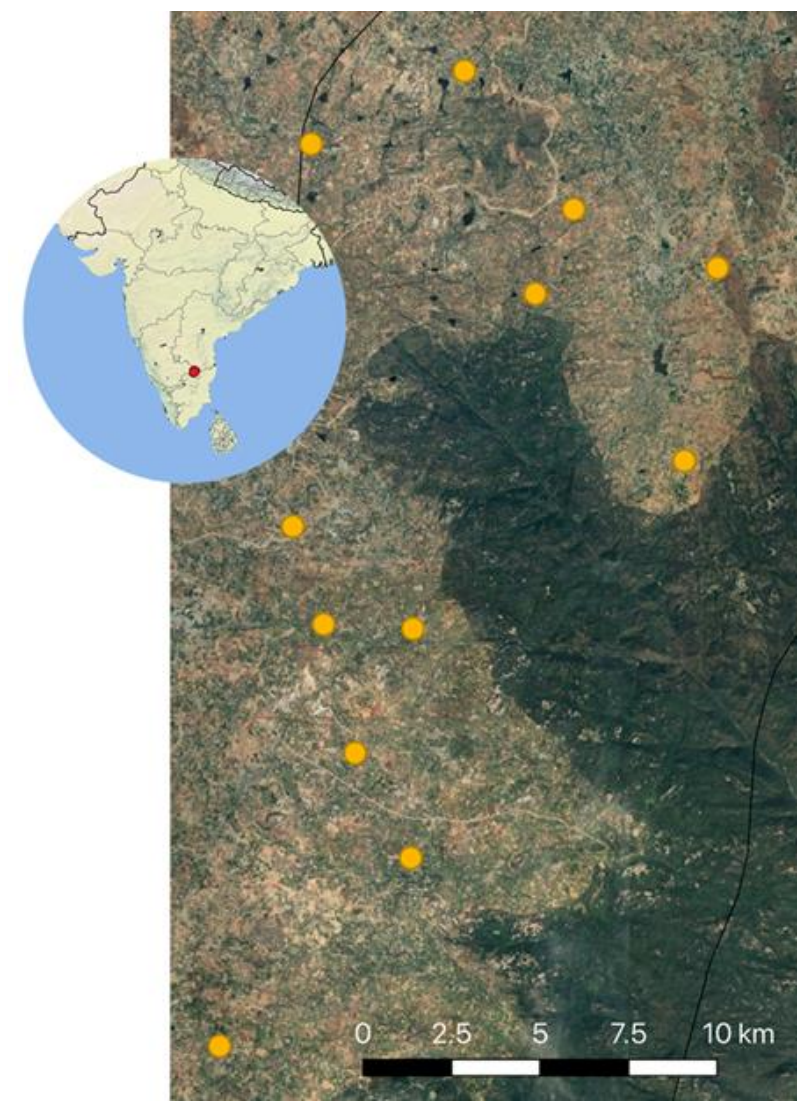

Figure 1. The location of chilli fields (yellow points). The study was conducted in the Chittoor district in the state of Andhra Pradesh, India.

\section{STUDY DESIGN}

Twelve chilli fields located at least $2.5 \mathrm{~km}$ from each other were selected (Fig. 1). The fields were selected such that a variation of landscape complexity was represented, by coarsely estimating the percentage of coherent seminatural vegetation (any vegetation or rocky outcrops that were clearly not cultivated) within $250 \mathrm{~m}$ in Google maps visually. This coarse measurement varied between 0 and $15 \%$ among the selected fields. Due to a leaf curl virus infection, one field was excluded during the course of the experiments resulting in eleven remaining fields. The chillies had been planted in November-December 2017. The size of the fields ranged from 0.070 to 0.25 ha $(0.14 \pm 0.065$ [mean $\pm \mathrm{SD}]$ ). Crop phenologies were rather synchronised, apart from one field being slightly earlier and two fields being slightly later than the rest. Farmers were interviewed about pesticide use, irrigation, and chilli variety. All farmers used pesticides, but chemical compositions and quantities applied could not be ascertained; we were mostly referred to the packages that were often thrown in the corners of the fields. The information on the packages revealed a wide variety of insecticidal and fungicidal compounds used, e.g. different neonicotinoids and systemic and contact fungicides containing Tricyclazole and Mancozeb. Three fields were irrigated through furrow irrigation, and nine fields through drip irrigation. We only got information from one of the farmers about variety of chilli, which was "Vaishnavi". The rest either did not inform us, or they stated they did not know or referred vaguely to it as hybrid varieties.

\section{POLLINATION EXPERIMENTS}

The pollination experiments started in the end of January in all fields except for the two phenologically later fields, where experiments started two weeks later. At the start of the experiment, the chilli plants had plenty of flower buds, and few, or no, open flowers. In each field, nine chilli plants at, or close to, the border of the field and nine chilli plants in the middle of the field were assigned to either have flowers excluded from pollinators with wind-permeable mesh bags (tailored with soft tulle fabric with $\sim 1 \mathrm{~mm}$ mesh size) placed around flowers, get pollen supplemented through hand pollination, or to stay untreated as controls (resulting in 18 experimental 
plants per field, and six plants of each treatment per field). The plants for the study were located such that there were at least two untreated plants between them, and the different treatments alternated so that two plants of the same treatments were not close to each other. On each plant, five flowers stalks were marked with pieces of plastic straw and subsequently treated (or left untreated in the case of controls). Hence, not all of the flowers on the plant were treated. Replication was thus done on three levels: five flowers per plant (all with the same treatment), six plants per treatment per field, and eleven fields. The marking and the application of mesh bags was done in the bud stage, and the pollen supplementation was done at a later visit when the marked flowers were fully open. Hand pollination was done with small paint brushes, by stroking the anthers of three freshly opened flowers from different (nonexperimental) plants and then stroking the stigma of the flower being pollen supplemented. Pollen amount and viability from donor flowers was not assessed. If the marked flowers had already flowered when visited for hand pollination, new nearby flowers (preferably on the same plant, but if not available, on a nearby plant) that were in the open flowering stage were marked and hand pollinated instead. The mesh bags over the pollinator excluded flowers were taken off at the first revisit when the flower petals had fallen off (or the whole flower had been aborted). Fruit set was thereafter assessed for all experimental flowers that could be assessed, excluding a few cases where markings or bags went missing. The final sample size can be seen in Appendix II. Fruit quality was also assessed, but due to accidental harvesting of experimental chillies in many of the fields (resulting in lower sample size and a harvest bias of nicer-looking fruits) only data on fruit set was used for statistical analyses. Presence/absence of aphid infestation and signs of leaf curl virus infection was noted for each experimental plant, and the abundance of thrips was sampled at the field level by counting the ones caught in six white pan traps that had been placed in the centre of each field and left for $48 \mathrm{~h}$.

\section{FLOWER VISITOR SURVEYS}

Flower visitor surveys were done by hand netting in the fields for 20 minutes while continuously walking around in the field, collecting and noting down any flower visitor on chilli within about $2 \mathrm{~m}$ in front of the surveyor. A stopwatch was used and stopped whenever an insect was handled. In cases where species determination could be done directly, the insects were released at the end of the survey, and if it was not the case, they were euthanised and subsequently pinned and identified to lowest taxonomical level possible, using available literature (Lieftinck 1962; Pauly 2009; Saini \& Vikram 2012; Rasmussen 2013; Veereshkumar 2015; Prashantha 2017; Ascher \& Pickering 2018). If a flower visitor was seen but not caught, the taxonomic identity was determined at the lowest taxonomical level possible in the field. The surveys were repeated three times in each field and were conducted on the following dates: Jan 25 - Feb 4, Feb 12-17, and Feb 26 - March 3. During the first survey two of the fields were skipped, because the chilli plants had not yet started to flower. Surveys were done between 9:00 and 13:00 $\mathrm{h}$, on days when wind speed was no higher than $5 \mathrm{~m} / \mathrm{s}$ and the temperature was between 20 and $40^{\circ} \mathrm{C}$. Wind speed and temperature was measured with a digital anemometer (AVM-06, HTC Instruments). During three of the survey days, pollen samples from the hindlegs of the most abundant chilli flower visitor, the giant honeybee (Apis dorsata), were collected and visually analysed for plant species determination. To this end, a total of 14 bees were sampled from 4 fields, and around 100 pollen grains from each sample were classified using a microscope with up to $100 \times$ magnification. The pollen clumps were individually dissolved in $75 \%$ ethanol and a small amount of the solution was placed on microscopic slides under a cover slide. The pollen grains in the samples were compared with reference samples of chilli pollen sampled directly from chilli flowers.

\section{DATA ANALYSIS}

Fruit set was analysed as a function of treatment and pest load (aphids, thrips and leaf curl virus) using a binomial generalised mixed model that took the nested design (plant/field) into account as random effects. The random effects were always possible to estimate. To assess the influence of flower visitor abundance on fruit set, a similar model was constructed that included an interaction between treatment and average flower visitor abundance (and not the pest covariates due 
to convergence problems). Final models were obtained with backward elimination based on $\mathrm{p}$ values, and variables were assessed with LR-tests. The final models only included variables with $\mathrm{p}$ values $<0.05$. All analyses and graphs were done in R (version 3.5.2, RCoreTeam 2019). Models were constructed with the glmer() function from the package lme4 (Bates et al. 2015). The DHARMa package (Hartig 2020) was used to visually assess model residuals and testing the uniformity (Kolmogorov-Smirnov test), dispersion, and outliers, and the function check_collinearity() from the package performance (Lüdecke et al. 2020) was used to check for collinearity. Model assumptions were fulfilled, and all VIF-values were $<2$ for both models. To compare the treatments, a Tukey posthoc test was done with glht() from the package multcomp (Hothorn et al. 2008), and the interaction between treatment and flower visitor abundance was analysed with testInteractions() from phia (Rosario-Martinez 2015). To make the graphs, the effects were extracted with effect () from effects (Fox 2003).

\section{RESULTS}

The fruit set was 73\% (CI 56-85\%) and 84\% (CI $70-92 \%)$ in the control and pollen supplemented treatments respectively, and 30\% (CI 17-48\%) in the pollinator excluded treatment (Fig. 2). The experimental treatments had clear effects (Fig. 2, $\chi^{2}$ $=66.2 ; \mathrm{df}=2 ; P<0.001)$, with higher fruit set from the two open treatments (control and pollen supplementation) than from the exclusion treatment $(\mathrm{z}=-5.8 ; P<0.001$ and $\mathrm{z}=-7.3 ; P<0.001$ for respective comparison). There was, however, no significant difference between the control and the pollen supplementation treatment $(\mathrm{z}=2.0 ; P=$ $0.11)$. None of the surveyed pests related to the fruit set.

Nearly all (98\%) of the flower visitors were bees, and the most common species were Apis dorsata (Giant honeybee), A. florea (Dwarf honeybee), and Tetragonula iridipennis (Indian stingless bee) (Fig. 3). All observed bee species are listed in Appendix I. The effect of flower visitor abundance on fruit set varied with treatment $\left(\chi^{2}=\right.$ 6.06; $\mathrm{df}=2 ; P=0.048)$, with all slopes being positive but were of different magnitude (control: $0.58 ; \chi^{2}=$ 2.9; $\mathrm{df}=1 ; P=0.27$, pollen supplementation: $1.2 ; \chi^{2}$ $=10.7 ; \mathrm{df}=1 ; P=0.004$, pollinator exclusion: 0.44 ; $\left.\chi^{2}=1.8 ; \mathrm{df}=1 ; P=0.53\right)$. The pollen sampled from the $14 \mathrm{~A}$. dorsata individuals consisted of only pollen of the chilli type, apart from one grain $(1 \%)$ in one sample.

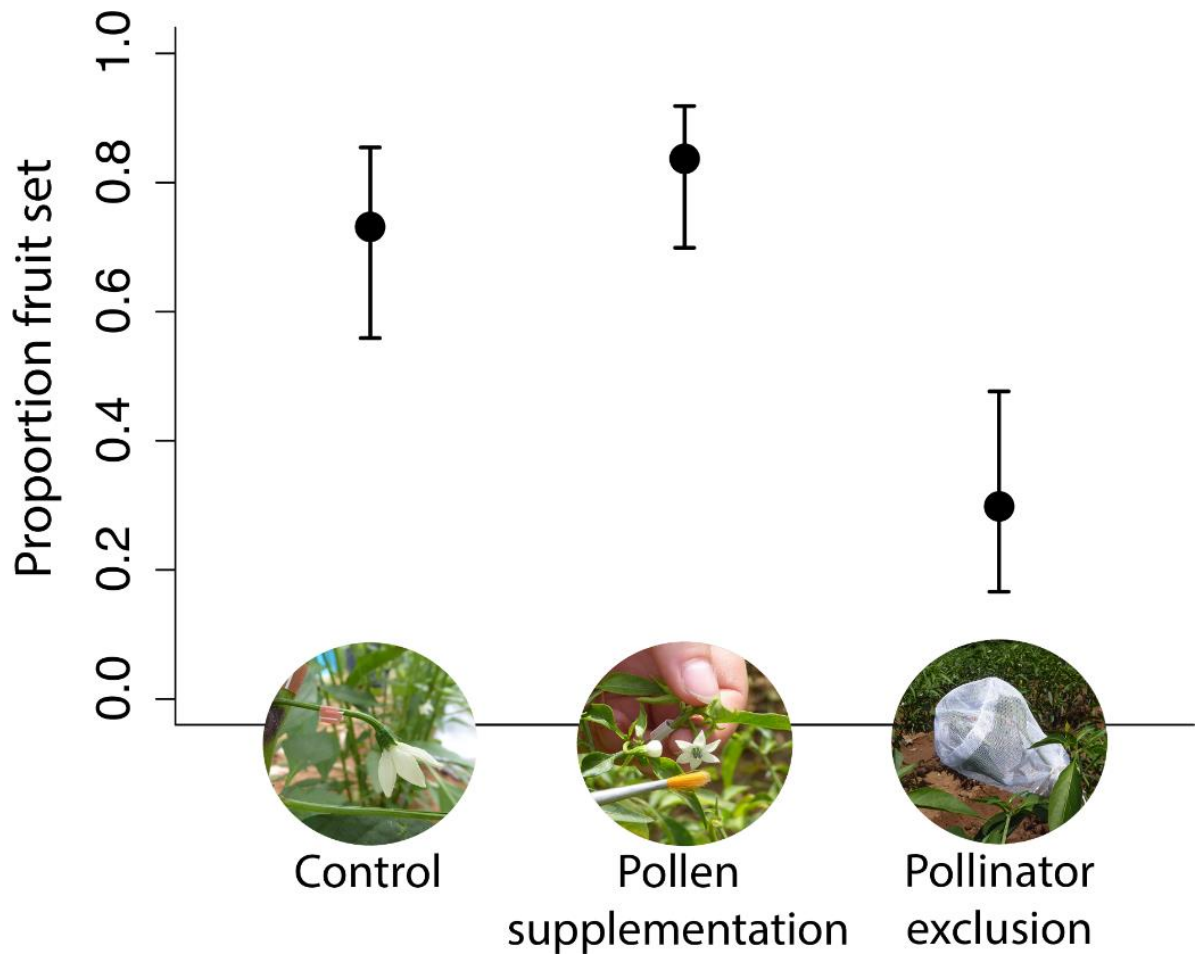

Figure 2. Fitted mean \pm $95 \% \mathrm{Cl}$ of fruit set in the three treatments control, pollen supplementation (hand pollination), and pollinator exclusion. 

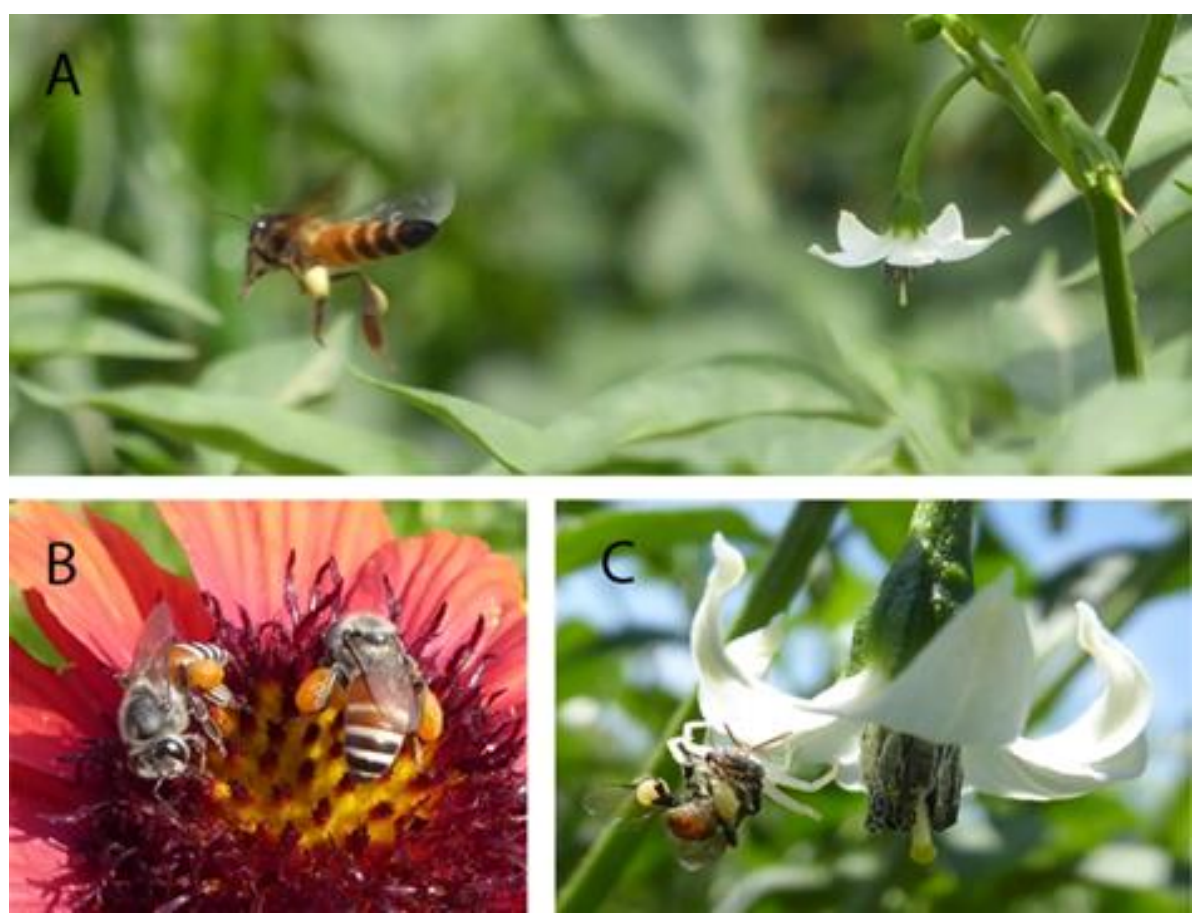

Figure 3. The three most common flower visitors $A$ ) Apis dorsata B) A. florea and C) Tetragonula irridipennis coll. (predated by a crab spider in the photo).

\section{DISCUSSION}

Chilli fruit set clearly benefits from insect pollination, most likely performed by wild bees, which were the dominant flower visitors. It has been shown in numerous greenhouse studies on chilli/bell pepper (both are C. annuum) that crosspollination or open pollination with added pollinators lead to higher yields than non-assisted self-pollination (Jarlan et al. 1997; Dag \& Kammer 2001; Ercan \& Onus 2003; Cruz et al. 2005; Azmi et al. 2016), and for the first time we show that pollinators are very important for chilli fruit set also under field conditions, where wind may also increase pollination (see also Carr \& Davidar 2015, although that study lacked replication). The results are further supported by evidence from studies of the closely related habanero, showing that insect pollination leads to higher habanero fruit set under outdoor conditions (Cauich et al. 2006; Landaverde-González et al. 2017). A lower fruit set may be compensated by larger fruits or increased flower numbers, but experimental evidence on greenhouse bell pepper suggest that the yield increase caused by pollinators derives from the number of fruits and not the size of fruits (Dag \& Kammer 2001). A. dorsata is likely to be the most important pollinator of chilli in the study area, as it is by far the most common flower visitor (Appendix I) and it collects pollen from chilli flowers, which means that the foragers are visiting many chilli flowers, potentially benefitting pollination. A. dorsata cannot be domesticated in hive boxes unlike some other honeybee species (Tan et al. 1997), and there is no general practice of beekeeping with other honeybee species (Apis spp.) in the area, which makes it likely that the local chilli is solely pollinated by wild bees and to some degree by wind. The mesh bags used in the experiment were wind permeable, and temperatures measured inside and outside the bags did not differ, indicating a similar microclimate in the pollinator exclusion treatment. However, in some cases it was observed that aphids multiplied more inside than outside the bags, possibly due to exclusion of natural enemies. This, together with the slight chance that bags possibly impeded wind pollination, suggests that wind pollination might contribute to slightly more than the $30 \%$ fruit set observed in this study.

We found no evidence for pollen limitation of chilli crops in the study area. The surrounding area supports a diversity of pollinating insects. This may compensate for any potential negative effects from e.g. pesticide loads (Rundlöf et al. 2015). Seven of the twelve participating farmers said that after applying pesticides they did not see many bees in the fields for a couple of days, but that they later returned. The most common flower visitors, A. dorsata, have very large colonies and commonly 
forage over several kilometres (Dyer \& Seeley 1991; Corlett 2011). This makes it more likely that any given chilli field will be visited by them, especially if it is an attractive resource to them (cf. Steffan-Dewenter et al. 2002). We found a positive relation between flower visitor abundance and fruit set, but it was only significant in the pollen supplemented treatment. We hypothesised that a higher flower visitor abundance would result in higher fruit set from the open pollinated plants, but not from the plants of the other two treatments. The significant positive effect from flower visitors seen in the pollen supplemented treatment but not in the open control is puzzling, because even if the hand pollination treatment did not result in perfect pollination, we should still see a significant effect on the open control plants as well. A likely explanation is that there is one or several unknown factors correlated with flower visitor abundance influencing all treatments, but that this by chance was significant only for the supplemented treatment. Because we did not observe any general pollinator limitation in the pollination experiment, the effect of flower visitor abundance is expected to be weak, or even absent if the abundance of pollinators is high enough for maximum pollination in all fields. The high fruit set from the open treatments (73 and $84 \%$ ) and the lack of evidence of pollen limitation in chilli crops should, however, not be seen as indicative for other insect pollinated crops grown in the area. For example, tomatoes and eggplant (with poricidal anthers), and many monoecious cucurbits may require higher abundances and more specialized pollinators than chilli for maximum fruit set and fruit quality (De Luca \& Vallejo-Marín 2013; Bomfim et al. 2016).

Because there are already indications of pollination service loss in India (Basu et al. 2011), it is of very high importance to do more research on crop pollination, both from a landscape ecological perspective, but also from a social perspective. From interviews with the twelve participating farmers, we found that only two thought that bees had a positive effect on chilli yields, while six of them thought that bees were negatively affecting the chilli yields, and four were neutral. Some thought that bees sucked out the essence from flowers that would otherwise have produced the fruits; they would remove bee nests close to their fields, or intentionally spray pesticide mixes at foraging bees. With the high proportion of small holdings in Indian agriculture (Tripathi \& Prasad 2010), raising awareness about the importance of pollinators is likely to be key for sustainable agriculture in India. The current economic value of crop pollination in India has been calculated as 22.5 billion USD annually, but the real number may be much higher, as pollination dependency data is lacking for many crops (Chaudhary \& Chand 2017). Additionally, because our results on chilli deviate from earlier conclusions mainly based on greenhouse studies, perhaps pollinator dependence has been underestimated in other crops as well. The increase in fruit set that we found may not necessarily lead to a proportional yield increase, but it is reasonable to believe that the yield effect from pollinators is considerably higher than the 0$10 \%$ stated in an often-cited review (Klein et al. 2007). Future research should establish to what degree the effect on fruit set also affects the fruit quality and total crop yield. Moreover, our results and bee observations underline the importance of wild pollinators in crop production (Garibaldi et al. 2013), providing an important ecosystem service that may be reduced or lost with agricultural intensification (IPBES 2016).

\section{ACKNOWLEDGEMENTS}

This project was funded by the Swedish Research Council (Swedish Research Links grant nr 2016-05635), granted to Almut Kelber, Hema Somanathan, and Henrik Smith. We want to thank Almut Kelber for initiating the over-arching project and for general and administrational support, Filippa Erixon and Michael Simmonds for help with fieldwork and bee identification, and Shylaja Rao for logistical support and communication help. We also thank the field station Kaigal with all its staff, the participating farmers, Romain Carrié and Ola Olsson for statistical support, John Ascher for identification support, and finally Vasuki Belavadi and colleagues from the Department of Entomology at the University of Agricultural Sciences (GKVK) in Bangalore, for offering identification facilities and advice. All collected specimens were donated to them.

\section{APPENDICES}

Additional supporting information may be found in the online version of this article:

Appendix I. Bee species and numbers.

Appendix II. Fruit set data per field. 


\section{REFERENCES}

Aizen MA, Garibaldi LA, Cunningham SA, Klein AM (2008) Long-term global trends in crop yield and production reveal no current pollination shortage but increasing pollinator dependency. Current Biology 18:1572-1575.

Aizen MA, Garibaldi LA, Cunningham SA, Klein AM (2009) How much does agriculture depend on pollinators? Lessons from long-term trends in crop production. Annals of Botany 103:1579-1588.

Ascher JS, Pickering J (2018) Discover Life bee species guide and world checklist (Hymenoptera: Apoidea: Anthophila). [online] URL: http://www.discoverlife.org $/ \mathrm{mp} / 20 \mathrm{q}$ ?guide=Apoidea species (accessed February 2018).

Azmi WA, Seng CT, Solihin NS (2016) Pollination efficiency of the stingless bee, Heterotrigona itama (Hymenoptera: Apidae) on chili (Capsicum annuum) in greenhouse. Journal of Tropical Plant Physiology 8:111.

Basu P, Bhattacharya R, Ianetta P (2011) A decline in pollinator dependent vegetable crop productivity in India indicates pollination limitation and consequent agro-economic crises. Nature Precedings.

Bates D, Maechler M, Bolker B, Walker S (2015) Fitting linear mixed-effects models using lme4. Journal of Statistical Software 67:1-48.

Bomfim I, Breno M, Fernando A, Stuart A (2016) Pollination in cucurbit crops. In: Pessarakli, M (ed) Handbook of cucurbits: growth, cultural practices, and physiology. CRC Press, Florida (US), pp 181-200.

Burkle LA, Marlin JC, Knight TM (2013) Plant-pollinator interactions over 120 years: loss of species, cooccurrence, and function. Science 339:1611-1615.

Carr SA, Davidar P (2015) Pollination dependency, pollen limitation and pollinator visitation rates to six vegetable crops in southern India. Journal of Pollination Ecology 16:51-47.

Cauich O, Quezada Euán JJG, Ramírez VM, ValdovinosNuñez GR, Moo-Valle H (2006) Pollination of habanero pepper (Capsicum chinense) and production in enclosures using the stingless bee Nannotrigona perilampoides. Journal of Apicultural Research 45:125130.

Chaplin-Kramer R et al. (2014) Global malnutrition overlaps with pollinator-dependent micronutrient production. Proceedings of the Royal Society B: Biological Sciences 281:20141799.

Chaudhary O, Chand R (2017) Economic benefits of animal pollination to Indian agriculture. Indian Journal of Agricultural Sciences 87:1117-1138.
Corlett RT (2011) Honeybees in natural ecosystems. In: Hepburn HR, Radloff SE (eds) Honeybees of Asia. Springer, pp 215-225.

Cruz DdO, Freitas BM, Silva LAd, Silva EMSd, Bomfim IGA (2005) Pollination efficiency of the stingless bee Melipona subnitida on greenhouse sweet pepper. Pesquisa Agropecuária Brasileira 40:1197-1201.

Dag A, Kammer Y (2001) Comparison between the effectiveness of honey bee (Apis mellifera) and bumble bee (Bombus terrestris) as pollinators of greenhouse sweet pepper (Capsicum annuum). American Bee Journal 141:447-448

De Luca PA, Vallejo-Marín M (2013) What's the 'buzz' about? The ecology and evolutionary significance of buzz-pollination. Current Opinion in Plant Biology 16:429-435.

Dyer FC, Seeley TD (1991) Dance dialects and foraging range in three Asian honey bee species. Behavioral Ecology and Sociobiology 28:227-233.

Ercan N, Onus AN (2003) The effects of bumblebees (Bombus terrestris L.) on fruit quality and yield of pepper (Capsicum annuum L.) grown in an uneated greenhouse. Israel Journal of Plant Sciences 51:275-283.

FAOSTAT (2020a) Food and Agriculture Organization of the United Nations (FAO). FAOSTAT Database: Crops and livestock products. Filters: India, Export Value, 2017 [online] URL: http://www.fao.org/faostat/en/?\#data/TP (accessed January 2020).

FAOSTAT (2020b) Food and Agriculture Organization of the United Nations (FAO). FAOSTAT Database: Crops. Filters: India, Area harvested, 2018 [online] URL: $\quad$ http://www.fao.org/faostat/en/\#country/100 (accessed August 2020).

FAOSTAT (2020c) Food and Agriculture Organization of the United Nations (FAO). FAOSTAT Database. [online] URL: http://www.fao.org/faostat/en/\#data/QC (accessed January 2020).

Fox J (2003) Effect Displays in R for Generalised Linear Models. Journal of Statistical Software 8:1-27.

Garibaldi LA et al. (2013) Wild pollinators enhance fruit set of crops regardless of honey bee abundance. Science 339:1608-1611.

Giannini TC, Cordeiro GD, Freitas BM, Saraiva AM, Imperatriz-Fonseca VL (2015) The dependence of crops for pollinators and the economic value of pollination in Brazil. Journal of Economic Entomology 108:849-857.

Goulson D, Nicholls E, Botias C, Rotheray EL (2015) Bee declines driven by combined stress from parasites, pesticides, and lack of flowers. Science 347:10.

Gupta AK (2004) Origin of agriculture and domestication of plants and animals linked to early Holocene climate amelioration. Current Science 87:5459 . 
Hartig F (2020) DHARMa: Residual diagnostics for hierarchical (multi-level / mixed) regression models. $\mathrm{R}$ package version 0.2.7. URL: https://CRAN.Rproject.org/package=DHARMa.

Hothorn T, Bretz F, Westfall P (2008) Simultaneous inference in general parametric models. Biometrical Journal: Journal of Mathematical Methods in Biosciences 50:346-363.

ILOSTAT (2020) International Labour Organization. ILOSTAT Country Profiles: India [online] URL: https://www.ilo.org/ilostatcp/CPDesktop/?list=true\&l ang=en\&country=IND (accessed August 2020).

IPBES (2016). The assessment report of the Intergovernmental Science-Policy Platform on Biodiversity and Ecosystem Services on pollinators, pollination and food production. Potts SG, ImperatrizFonseca VL, Ngo HT (eds). Secretariat of the Intergovernmental Science-Policy Platform on Biodiversity and Ecosystem Services, Bonn, Germany, 827 pp.

Jarlan A, De Oliveira D, Gingras J (1997) Pollination by Eristalis tenax (Diptera: Syrphidae) and seed set of greenhouse sweet pepper. Journal of Economic Entomology 90:1646-1649.

Klein AM et al. (2007) Importance of pollinators in changing landscapes for world crops. Proceedings of the Royal Society B: Biological Sciences 274:303-313.

Kohli RK, Batish DR, Singh HP, Dogra KS (2006) Status, invasiveness and environmental threats of three tropical American invasive weeds (Parthenium hysterophorus L., Ageratum conyzoides L., Lantana camara L.) in India. Biological Invasions 8:1501-1510.

Kottek M, Grieser J, Beck C, Rudolf B, Rubel F (2006) World map of the Köppen-Geiger climate classification updated. Meteorologische Zeitschrift 15:259-263.

Landaverde-González P et al. (2017) Sweat bees on hot chillies: provision of pollination services by native bees in traditional slash-and-burn agriculture in the Yucatán Peninsula of tropical Mexico. Journal of Applied Ecology 54:1814-1824.

Lieftinck MA (1962) Revision of the Indo-Australian species of the genus Thyreus Panzer (= Crocisa Jurine) (Hym., Apoidea, Anthophoridae) Part 3. Oriental and Australian species. Zoologische Verhandelingen 53:1212.

Lowder SK, Skoet J, Raney T (2016) The number, size, and distribution of farms, smallholder farms, and family farmsworldwide. World Development 87:16-29.

Lüdecke D, Makowski D, Waggoner P (2020) performance: Assessment of regression models performance. $\mathrm{R}$ package version 0.4.4. URL: https:/CRAN.R-project.org/package=performance.
Mishra V (2002) Population growth and intensification of land use in India. International Journal of Population Geography 8:365-383.

Ollerton J, Winfree R, Tarrant S (2011) How many flowering plants are pollinated by animals? Oikos 120:321-326.

Pauly A (2009) Classification des Nomiinae de la Région Orientale, de Nouvelle-Guinée et des îles de l'Océan Pacifique (Hymenoptera: Apoidea: Halictidae). Bulletin de 1'Institute Royal des Sciences Naturelles de Belgique 79:151-229.

Prashantha C (2017) Taxonomic Studies on carpenter bees (Hymenoptera: Apidae: Xylocopinae) of Karnataka, University of Agricultural Sciences GKVK, Bengaluru.

Rasmussen C (2013) Stingless bees (Hymenoptera: Apidae: Meliponini) of the Indian subcontinent: Diversity, taxonomy and current status of knowledge. Zootaxa 3647:401-428.

RCoreTeam (2019) R: A language and environment for statistical computing. R Foundation for Statistical Computing, Vienna, Austria. URL: https://www.Rproject.org/.

Reddy CS et al. (2008) Mapping the vegetation types of Andhra Pradesh, India using remote sensing. Proceedings of the Andhra Pradesh Akademi of Sciences 12:14-23.

Rosario-Martinez HD (2015) phia: Post-Hoc Interaction Analysis. $\mathrm{R}$ package version 0.2-1. URL: https://CRAN.R-project.org/package=phia.

Rundlöf $M$ et al. (2015) Seed coating with a neonicotinoid insecticide negatively affects wild bees. Nature 521:77-80.

Saini M, Vikram RS (2012) A species checklist of family Halictidae (Hymenoptera: Apoidea) along with keys to its subfamilies, genera \& subgenera from India. International Journal of Environmental Sciences 3:134.

Steffan-Dewenter I, Munzenberg U, Burger C, Thies C, Tscharntke $T$ (2002) Scale-dependent effects of landscape context on three pollinator guilds. Ecology 83:1421-1432.

Tan NQ, Chinh PH, Thai PH, Mulder V (1997) Rafter beekeeping with Apis dorsata: some factors affecting the occupation of rafters by bees. Journal of Apicultural Research 36:49-54.

Tripathi A, Prasad A (2010) Agricultural development in India since independence: A study on progress, performance, and determinants. Journal of emerging knowledge on emerging markets 1:63-92.

Veereshkumar (2015) Taxonomic studies on leaf cutter bees (Hymenoptera: Megachilidae) of Karnataka, University of Agricultural Sciences GKVK, Bengaluru.

WorldWeatherOnline (2020) Chittoor monthly climate averages [online] URL: 
https://www.worldweatheronline.com/chittoor-

weather-averages/andhra-pradesh/in.aspx (accessed

August 2020).

(cc) BY

This work is licensed under a Creative Commons Attribution 3.0 License. 